\title{
Governance challenges of mobility platforms: the case of Merwede, Utrecht
}

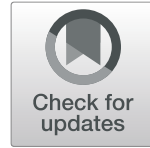

Martijn van den Hurk ${ }^{1 *}$, Peter Pelzer ${ }^{1}$ and Rianne Riemens ${ }^{2}$

\begin{abstract}
Background: Merwede is an envisioned neighbourhood in Utrecht (the Netherlands) that provides an instructive case to learn about the governance challenges of digital mobility platforms. Unique about Merwede is how the development of a mobility platform is envisioned to be integrated into the development of a new neighbourhood.

Methodology: This article discusses the case of Merwede and provides insights into its proposed mobility platform and how it is made. It illuminates governance challenges relevant to the design and operation of an unconventional mobility concept by disentangling outstanding practical issues concerning three key governance dimensions_-organizational structures, decision-making processes, and instruments.

Results: The research provides an empirical illustration of governance questions that come up when mobility becomes a service and is integrated into the urban fabric from the very beginning of a development process. Already in the plan development stage, Merwede illustrates that difficult decisions are to be made and competing interests come to the fore.
\end{abstract}

Keywords: Mobility platforms, Urban planning, Area development, Governance, The Netherlands

\section{Introduction}

The climate crisis and a soaring urban population are two urgent planning issues. City governments are increasingly feeling the need to adapt to and mitigate climate change. Furthermore, physical and institutional interventions on housing markets are considered necessary to keep or render cities affordable and accessible for their communities [35]. Against this backdrop, densification has increasingly been considered a potential way forward in designing and building cities (see for instance $[3,9]$ ), which has direct implications for mobility. While monofunctional neighbourhoods with either residential or commercial functions trigger commuter flow, higher density increases the potential for public transit and active modes like bicycling and walking $[4,30,37]$. Densification implies what we refer to here as a consideration of mobility arrangements: configurations of (1) land use, (2) mobility services, and (3) mediation platforms between land use and mobility services. Examples of

\footnotetext{
* Correspondence: m.h.h.vandenhurk@uu.nl

${ }^{1}$ Department of Human Geography and Spatial Planning, Utrecht University, Princetonlaan 8a, 3584, CB, Utrecht, The Netherlands

Full list of author information is available at the end of the article
}

such new arrangements include shared-vehicle fleets that are connected to urban development projects, and car traffic-free neighbourhoods with collectively owned parking structures at the edges (see for instance [34]).

Such new mobility arrangements often rely on digital technologies to connect demand and supply through a digital infrastructure that can help to address mobility challenges [50]. Here, a key role is played by digital platforms: "(re)programmable digital infrastructures that facilitate and shape personalized interactions among end-users and complementors, organized through the systematic collection, algorithmic processing, monetization, and circulation of data" ([41], p. 3). Being algorithm-driven solutions, they can steer or nudge user behaviour to improve user experiences as well as the efficiency of a mobility system at large. However, these digital solutions tend to come with two caveats.

First, the implementation of mobility innovations often precedes political debates: it circumvents democratic mechanisms, thereby excluding conversations on how public values are (to be) affected and which public values are (to be) prioritized (cf. [32, 33]). It tends to be after a new phenomenon has established in a city-e.g. when 
Airbnb has become a nuisance for residents-that governments develop regulations to solve problemse.g. to address a large tourist population. Second, technological mobility solutions are generally scoped in isolation from spatial context and existing mobility arrangements. The risk is that a discrepancy unfolds between envisioned solutions and how they work in the real, physical environment. For instance, a platform's vision may not be tailored to a city's needs and be out of sync with the locale where it is implemented [39]. Different countries, cities, and neighbourhoods come with different governments, political ideologies and visions, cultures and communities, preferences, and physiques. A digital innovation may be helpful in one neighbourhood, yet unnecessary or dysfunctional in another (cf. [23]).

The objective of this article is to empirically unpack the governance questions that come up in a case where densification meets platform mobility. Central in this analysis is the case of Merwede, an envisioned neighbourhood in the Dutch city of Utrecht, with a density of well over 200 dwellings per hectare. Concomitant with this high density, car ownership and use are deprioritized. The projected density requires a shift from 'owning' mobility to 'using' mobility. The Utrecht local government is in the proverbial driver's seat: it develops the rules for a digital mobility innovation before that innovation is implemented. Furthermore, the innovation is to be part and parcel of the new neighbourhood: to avoid isolation of 'the digital' from 'the physical', the making of the mobility concept is integrated into the development process from the outset. The plans for the new neighbourhood have received critical acclaim, both nationally and internationally (see for instance $[5,42]$ ). As an extreme case-i.e. an early adopter of a radically different strategy of building urban neighbourhoodsMerwede provides a rich empirical demonstration of governance challenges and unfolds theoretical implications [31].

The article is structured as follows. First, it addresses mobility platforms and connects them to planning practice and governance challenges. Second, the article introduces the case of Merwede and addresses the methodological aspects of the research. We then move on to an empirical illustration of governance challenges based on an analysis of the making of a mobility concept for Merwede. Based on earlier research about the governance of urban development projects, these challenges are divided into three categories: (1) setting up organizational structures, (2) running decision-making processes, and (3) developing and operating the instruments necessary to make a mobility arrangement work. The article concludes with a summary of the findings and critical reflections.

\section{Platform urbanism and its implications}

The infrastructural presence of platforms in urban environments marks the rise of platform urbanism: an intertwinement of platforms and urban space, "operationalized via (social) mobile navigation applications and played out on public roads, in particular, and the information public sphere, more generally" ([50], p. 366; see also [2]). Mobility platforms do not merely connect supply and demand of transport; processes of platformization "affect $[\mathrm{s}]$ the entire sector, effectively blurring the division between private and public transport modalities; existing public-private arrangements have started to shift as a result" ([52], p. 75) (emphasis in original). Thus, while platforms and digital technologies introduce a new dimension to conventional planning practices, they also affect the overall governance of planning practices. Van Doorn [53], p. 1817) brings in Airbnb as an example, where "politics are intrinsic to and indissociable from the operations of its platform" (emphasis in original). As a new governing actor within the sectors of tourism and housing, Airbnb is setting new norms and standards for how interaction is organized, without taking responsibility for the consequences. The platform enables citizens to monetize their house as a form of income, thereby causing inequalities in wealth between house owners and non-owners as well as a housing shortage [53]. Similarly, digital platforms present new challenges to planning practitioners by shifting the relations between parties involved in city building [50]., p. 365) speak of "a seeming 'digital standoff '... between city planners and application providers as well as drivers using or even contributing information to the navigation applications." Concluding from their research on traffic and navigation platform Waze, Van der Graaf and Ballon argue that while the privatization of the public sphere might not be new, the pervasiveness of and lack of transparency about the control and ownership within "complex multi-stakeholder platformbased ecosystems" is ([50], p. 371).

The rise of on-demand mobility services such as Uber, Lyft, and Blablacar exemplifies the digitization of the urban environment: these services allegedly provide faster and more efficient trips from $\mathrm{A}$ to $\mathrm{B}$, focusing on customer experience (e.g. a quick, cheap and smooth trip) and corporate interests (e.g. efficiency gains, data utilization) [52, 55]. However, services such as Uber might affect the city as a whole negatively: more accessible mobility solutions could, for instance, trigger the demand for mobility ('induced demand'), increase congestion, and boost emissions (e.g. $\mathrm{CO}_{2}$ ). Similar to Airbnb, mobility platforms may fulfil the needs of individuals, but harm the collective interest as they function disconnectedly from the physical environment. Moreover, as highlighted by the concept of reverse technology 
assessment [32], it is often after a particular platform or service has been implemented and becomes operational that societal or political debate is sparked and legislation and regulation become the subject of public debate. By then, for authorities, the only way forward is to either allow or prohibit the platform or service in question, as happened in some Dutch cities with UberPop [40]. Is there an alternative?

Several scholars address the central role governments ought to play. According to Meijer [38], p. 196), "datainfrastructures embody value judgments about the city and thus are not neutral tools but mechanisms for governing the political community of citizens." Docherty [24] argues that it is not a question if governments have to play a role in this digital transition, but how. A potential change of tack for policymakers (including planners) would be to assume a more proactive role, by acknowledging the digital dimension in urban planning and the increasing role of algorithms in shaping urban life, and by reshaping their tasks and responsibilities to safeguard and promote public interests [23]. Van der Graaf and Ballon weigh into this conversation by proposing a move towards "an 'architecture of opportunities' where public and private urban design professionals as well as citizens need to reconsider their own role and ownership in 'city making' that is not only smart but foremost human" ([50], p. 371). Likewise, Pangbourne et al. [39] argue that MaaS (Mobility-as-a-Service) is not to be merely considered as a separate private-sector business opportunity. Instead, it should be internalized in public strategic urban plans that mobility platforms are integrated into the larger urban agenda.

\section{Literature gap: governance challenges in urban development}

In line with the aforementioned calls for alternative strategies, local governments have increasingly been taking a more proactive approach to resolving mobility questions. For instance, they have been formulating instructions for mobility platforms and their integration into urban environments while these environments are being developed-e.g. incorporating the making of mobility platforms into the making of new neighbourhoods. However, developing such alternative, often unconventional solutions implies significant challenges of governance. In this article, we focus on governance as the making and operating of new organizational structures, decision-making processes, and instruments $[7,44,46]$, in settings that are characterized by complicating questions of political and technical nature, and by the involvement of a multitude of actors (cf. [49]).

Scholars of platform urbanism and smart mobility have written extensively on the governance challenges entailed to these endeavours, generally based on empirical research. For instance, Docherty et al. [25], p. 114) discuss at length how "changing networks of actors, resources and power, new logics of consumption, and shifts in how mobility is regulated, priced and taxed" affect the safeguarding of public value and thus require deep discussions on governance. Furthermore, based on a study of 200 urban mobility platforms, Stehlin et al. [45] signal five trajectories of platform formation. One of these trajectories, labelled 'Governmental fix', comprises governments (EU, regional, local) that establish mobility platforms to promote social values. These are often integrative, all-in-one MaaS portals that operate at city-regional scale and integrate public and private services. However, where mobility platforms truly meet urban planning, i.e. where a mobility arrangement is integrated into the development process of, for instance, a new neighbourhood, empirical research has been lacking. Yet, there has been increasing interest and action among (local) governments in exploring the potential of high-density urban neighbourhoods with alternative mobility schemes including digital mobility platforms for instance in the neighbourhoods of Kalasatama (Helsinki) and Binckhorst (The Hague). There is a need for both acquiring and sharing empirical, practice-oriented knowledge on this topic.

Furthermore, integrating mobility arrangements, including digital mobility platforms, into development processes has the potential to develop more refined conceptual insights on the governance of platform urbanism. We foresee a novel set of governance challenges related to platform urbanism of the type that we see in Merwede, because such cases of platform urbanism include different (1) organizational structures, (2) decisionmaking processes, and (3) instruments than most other cases of platform urbanism have depicted so far (cf. [39, 45]).

First, as for organizational structures, integrating mobility arrangements into development processes implies a different constellation of actors. For instance, the typical start-ups and tech firms that are common players in platform urbanism [45] are not nearly as important when a municipality and several real estate developers and investors determine the agenda for a future neighbourhood. Landownership becomes a key factor as the mobility concept can only become a success if all landowners on a project site endorse the mobility plan-and are willing to pay for it.

Second, decision-making processes on spatial planning are inherently public processes that come with different types of diligence and scrutiny than making a mobility platform for private, commercial use alone. Designing and establishing land-use plans (zoning plans) and receiving planning permission from local government require thorough public accountability procedures. Also, 
the involvement of many different actors (landowners) implies diverging preferences regarding project content and timing. As a result, it takes a significant amount of time to come to development agreements.

Third, regarding instruments, where platforms meet planning there is no such thing as simply 'plugging' a digital platform and operating an app. Where local government is involved as an initiator, the search for a platform designer and/or operator has to occur through procurement. This type of procedure generally comes with a lengthy tender process, including complex negotiations between clients and potential contractors, which eventually leads to a private-law agreement (i.e. a contract). Writing and 'closing' contracts requires clarity about the likes of definitions, obligations, and enforcement mechanisms.

All in all, these peculiarities create a different and largely unaddressed set of governance challenges. In this article we explore these challenges by zooming in on what has occurred so far in the development process of Merwede. We consider this case a frontrunner that showcases an early attempt at connecting urban development to mobility platforms.

\section{The case of Merwede}

Located in Utrecht, the district Merwedekanaalzone will be turned into a mixed-tenure, mixed-use urban district over the next two decades, and Merwede (the focus of this article) is part of this large-scale redevelopment. The proposal for Merwede is to develop 6000 dwellings in an area of approximately 25 ha as part of the urban fabric of Utrecht, the fastest-growing city in the Netherlands. However, realizing this development with a conventional car-parking norm of between 0.7 and 1 per household would increase traffic generation in the area so dramatically that the City of Utrecht would not be allowed to proceed with the plan due to road capacity constraints and safety issues $[1,6,54]$. A traditional mobility scheme focused on car ownership and use has therefore been out of the question.

Building Merwede proved only feasible if combined with an innovative mobility arrangement that would significantly limit traffic generation. Therefore, the City of Utrecht $[21,22]$ has been preparing an arrangement for Merwede that consists of three elements: (1) a spatial configuration including a public space that facilitates active transport, connects well to public transit, and is largely free of cars; (2) a parking concept for cars that involves a low parking norm of 0.3 per residence ${ }^{1}$ and a

\footnotetext{
${ }^{1}$ Utrecht's parking policy aims for a parking norm of approximately 1.0 for large apartments in dense urban areas and a minimum norm of 0.38 for smaller apartments. In lower-density areas the parking norm is typically higher (around 2.0) [11].
}

plan for parking at a distance (at designated Park \& Ride locations); and (3) several mobility hubs, which include mobility services, mobility shops, and a digital platform. These hubs are planned to offer "attractive, easily accessible and affordable (shared) mobility services," on a $24 / 7$ basis, to inhabitants and visitors of Merwede [22]. Physical mobility shops will be the places to go to for picking up packages and customer service. A digital platform has been proposed to bring together the demand for and supply of services, offering a marketplace where users can plan, book, and pay for mobility [20].

Four provisional requirements have been set for the platform: (1) inhabitants and visitors should be able to arrange and pay for mobility services in one app; (2) the app should aim to fulfil the individual needs of users, offering different prices and membership or subscription types; (3) the platform should monitor travel behaviour and become more intelligent over time so that it gets better at predicting the use of mobility services (i.e. it should be selflearning); and (4) the platform should anticipate demand at all times and thus be able to adequately deal with contingencies (e.g. changing weather conditions, congestion, malfunctions) ([6], p. 11 [51]; p. 13).

The planning of Merwede has been in progress since the early 2000s. An early version of a new plan for the entire Merwedekanaalzone was presented in 2004 [10], but a new version did not come to fruition until after the 2007-2008 global financial crisis. In 2015, Utrecht's local government embraced 'healthy urban living' as the new motto for the development of the city. This implied a new spatial planning strategy, focusing on densification and the proliferation of active transport [12-17]. Under the umbrella of this new strategy, concrete plans for the Merwedekanaalzone, and more specifically Merwede, started to unfold. Several vision documents, mobility reports, and environmental studies were published in 2017 and 2018 [1, 6, 18, 19, 26], followed by further formal documentation on the urban plan and its affiliated mobility concept in 2019 and 2020 [20, 21, 27, 28, 36].

Although at the time of writing (fall 2020) a land-use plan has yet to be developed, several key decisions for Merwede have been made. For instance, within the 25 ha of the project site, no more than 1800 parking spots will be available for 6000 homes; parking spots can only be rented, not purchased; and approximately one-fifth of these spots will be reserved exclusively for shared cars. These arrangements have been included in a term sheet, signed by the City of Utrecht and six developers, which sets forth the basic (and non-binding) terms and conditions for developing the new neighbourhood. This term sheet will be followed by a (binding) partnership agreement before the preparations for a land-use plan commence. Table 1 provides a technical overview of Merwede and summarizes the planning process up until 2020. 
Table 1 Provisional overview of Merwede-technical specifications and chronology of planning process (adapted from workshop P1; see Section 5 on methods)

\begin{tabular}{ll}
\hline Technical information & \\
Location & Utrecht \\
Area & 25 ha \\
Previous functions & Light industry; logistics/distribution; offices \\
Envisioned functions & Mixed-use area: housing, offices, public \\
& amenities \\
Mobility concept & - Spatial configuration: public space stimulates \\
& active transport and public transit; \\
& discourages or prohibits car traffic \\
& - Parking concept: parking norm of 0.3 per \\
& residence; parking at a distance \\
& - Mobility hubs: mobility services, physical \\
& mobility shops, and digital platform \\
& -1800 parking spots for cars in total-1200 \\
& spots underground, 600 'transformative' \\
Physical mobility & spots above ground (which technically \\
aspects (selection) & enables decreasing the parking norm to less \\
& than 0.3 if required) \\
& Of which: \\
& -1400 for private cars \\
& -350 for shared cars \\
& -50 for disability parking \\
& - Max. 700 at a distance
\end{tabular}

\section{Process}

2004

2012

2015-2016

2017-2018

2019-2020

In progress

Not started

${ }^{\mathrm{a}}$ These figures are unconfirmed as planning and negotiation processes are ongoing at the time of writing (fall 2020)

\section{Methods}

Our research approach has been transdisciplinary: we responded to, and actively engaged in, a policy challenge the City of Utrecht grappled with: making a mobility concept for Merwede. We observed this process and flagged governance questions and dilemmas as they unfolded. During this process, we gathered data in three ways to assemble an overview of the governance questions that occurred in practice. First, we collected documents at Utrecht's local government that were directly related to the planning process for Merwede, including the mobility platform. These documents included internal and sometimes embargoed project information, but also publicly available material. Second, we conducted exploratory interviews with actors involved in the Merwede project and mobility experts. We talked to 10 interviewees in total: two managers of mobility projects at the City of Utrecht; two consultants that advise the municipality on Merwede's mobility concept; one private developer who owns land on the Merwede project site; two academic scholars of mobility; and three public officials outside Utrecht who manage MaaS programs and projects. The interviews took $45 \mathrm{~min}$ on average. We asked respondents outside of Merwede primarily questions about lessons that they learned from mobility platforms that they had studied or been involved in. Respondents involved in Merwede would receive questions that were tailored to the respective mobility platform and urban development. Third, we hosted several workshops with public officials and mobility experts in which we discussed the foundations for the mobility platform. These exercises helped unveil the critical decisions and dilemmas that policymakers deal with in cases like Merwede. Table 2 provides an aggregated overview of the data collection.

We analysed policy and project documentation, interview summaries, and workshop reports using the aforementioned threefold division of governance dimensions: organizational structures, decision-making processes, and instruments [7, 44, 46]. As an analytical framework, these three dimensions helped us to recognize and assess governance challenges as follows. First, we would allocate a challenge to the dimension of organizational structures when it concerned the actor constellation: the actors involved and the accountability lines and allocation of tasks and responsibilities between these actors. Second, when we came across issues regarding public participation and the phasing of Merwede's development, we would recognize these as questions of decision-making processes. Third, where the case material put forward matters such as definitions of the mobility platform, financial resources, and contracts, we would put those in the category of instruments. Ultimately, our interpretations resulted in three clusters of empirical findings. This article highlights some of the most pertinent governance challenges of Merwede; the questions that have remained outstanding despite several years of preparations by and negotiations between the City of Utrecht and other stakeholders involved in the development.

\section{Governance challenges in Merwede}

Based on our analysis, we discuss the most pertinent challenges about the governance of the mobility arrangement for Merwede, focusing respectively on organizational structures, decision-making processes, and instruments. 
Table 2 Aggregated overview of data collected and analysed for this study

\begin{tabular}{ll}
\hline Documents & Number \\
\hline Policy documents (Utrecht's policies for mobility and planning, 2004-2020) & $9^{\text {a }}$ \\
Project documentation (environmental assessment, mobility concept, urban plan, and market consultation) & $8^{\text {a }}$ \\
Interview respondents & 5 (respondents S1- \\
Stakeholders involved in Merwede (two mobility project managers at City of Utrecht, two mobility consultants, one private & 5 ) \\
developer) & 5 (respondents M1- \\
Mobility experts (two mobility scholars, three mobility program or project managers at other governments) & 5 ) \\
Workshops & 3 (workshops P1-3) \\
Partner meetings (with City of Utrecht and/or Rathenau Instituut) & 4 (workshops E1-4) \\
Expert meetings (with academic scholars) & 3 (workshops F1-3) \\
Feedback sessions (external presentations followed by Q\&A and discussions) &
\end{tabular}

${ }^{a}$ These numbers refer to key public documents; they do not include project briefings to city council, appendices to official documents, or other supporting documentation

\subsection{Organizational structures}

Our analysis of Merwede's mobility concept from the perspective of organizational structures laid bare ambiguities and risks related to ownership and responsibility, both during the development phase and the operational phase.

\subsubsection{Developing the mobility concept: different perspectives} A key point of contention has been the two-sided position of the City of Utrecht relative to the entire constellation of actors. First, in its position as a landowner, the City of Utrecht has been part of the Collective of Owners, a group of actors (seven in total) who possess land on the project site. Next to the City of Utrecht, this group includes six developers and investors, and it has reserved an amount of 7 million euros for the mobility concept for Merwede: to develop and implement it, and to cover any start-up losses for a platform and service operator. The municipality owns $35 \%$ of the land in the project area. It is likely that at some point it will sell this land to generate revenue. Here, it acts as a private agent in the project. Second, as a public actor, it is in charge of making land-use plans and providing planning permissions. In this public role, the municipality pursues to defend and promote public values rather than play an entrepreneurial role (cf. [8]). As a result, the City of Utrecht is both a developer and a regulator in Merwede, and this peculiar position generates debate about whose side it is on. On the one hand, it is in the interest of the municipality to make a success of the digital mobility platform, to make it serve public values and render mobility accessible to as many users as possible, which can be done by setting standards and rules for development. On the other hand, in its role as a landowner in Merwede and financial contributor to the mobility concept, a bold, expensive, and risky mobility scheme might threaten the proceeds from the land sales.
The public ambitions of the City of Utrecht, which are to downplay the role of the car in Merwede, demand risk-taking on the part of the landowners (including the City of Utrecht as a private agent). This has complicated the development of Merwede. For instance, the planned number of parking spots for shared cars versus privately owned cars has become an issue. While the plan has been to allocate approximately 350 parking spots to shared cars and increase this number over time, landowners have been cautious about this proposed composition of the parking facility. They have worried that the marketability of homes without parking space is limited (Respondent S1). As a private agent, the City of Utrecht will eventually try to sell land for development. Therefore, it has had an interest in mitigating risk and downplaying the boldness of the mobility concept, rendering it feasible for developers to proceed with the plans. Here, its private ambitions oppose its public ambitions. We observed similar tensions regarding the number of parking spots to be built underground; these are costly operations that suit the public ambitions of the local government, yet hamper financial feasibility for landowners.

\subsubsection{Mobility operations: new roles and responsibilities}

Table 3 provides an overview of the actors involved in Merwede. It lists the City of Utrecht and the Collective of Owners, who are the key players in the development phase. The number of (potential) actors involved will increase during the operational phase of Merwede's mobility concept. The Collective of Owners has made clear that it prefers to run a tender for parts of the operation of the mobility concept [22]. Challenges of ownership and responsibility regarding mobility extend into the operation of the neighbourhood, the mobility hubs, and the digital platform. This is a direct consequence of the ambition to integrate a mobility arrangement into a new 
Table 3 List of (potential) key actors involved in the development of Merwede (adapted from [6], pp. 17-18 [22];)

\begin{tabular}{|c|c|c|}
\hline Actors & $\begin{array}{l}\text { Phase(s) of } \\
\text { involvement }\end{array}$ & Responsibilities \\
\hline $\begin{array}{l}\text { Landowners, united in a Collective of Owners (six } \\
\text { developers and the City of Utrecht (as a private agent)) }\end{array}$ & $\begin{array}{l}\text { Development phase } \\
\text { and operational phase }\end{array}$ & $\begin{array}{l}\text { - Developing physical elements of mobility concept (e.g. parking } \\
\text { spots, mobility shops) and public space (e.g. bicycle bridges) } \\
\text { - Selling physical elements of mobility concept (when completed } \\
\text { and operational) }\end{array}$ \\
\hline City of Utrecht (as a public agent) & $\begin{array}{l}\text { Development phase } \\
\text { and operational phase }\end{array}$ & $\begin{array}{l}\text { - Implementing mobility policies that support mobility concept } \\
\text { (e.g. parking policy, bicycle policy, Park \& Ride) } \\
\text { - Aligning mobility policies and contracts with other governments } \\
\text { - Investing in public infrastructure }\end{array}$ \\
\hline Mobility enterprise (including mobility director) & Operational phase & $\begin{array}{l}\text { - Safeguarding, operating and further developing mobility concept } \\
\text { (e.g. quality management, traffic control) } \\
\text { - Owning or renting parking spots, renting mobility shop } \\
\text { - Monitoring and tweaking progress and use of mobility concept } \\
\text { - Managing contract(s) with service operator(s) } \\
\text { - Coordination partnership between parties involved (e.g. } \\
\text { landowners, City of Utrecht, real estate owners) for mobility } \\
\text { issues }\end{array}$ \\
\hline Mobility service operator(s) & Operational phase & $\begin{array}{l}\text { - Recruiting and coordinating transport provider(s) } \\
\text { - Providing memberships/subscriptions and collecting service fees } \\
\text { - Operating digital platform } \\
\text { - Operating mobility shop (customer service) } \\
\text { - Overseeing further development of services }\end{array}$ \\
\hline Transport provider(s) & Operational phase & - Providing mobility service(s) \\
\hline User(s) & Operational phase & - Using mobility service(s) \\
\hline Parking operator(s) & Operational phase & $\begin{array}{l}\text { - Operating parking garages (e.g. reservation system, regulation of } \\
\text { access) }\end{array}$ \\
\hline
\end{tabular}

neighbourhood, and it implies the engagement of new institutions.

Project documentation and interview respondents indicated that a mobility enterprise will be established. The mobility enterprise is said to become the central actor in governing Merwede's mobility concept [22]. The City of Utrecht and the Collective of Owners intend to set up this new organization as a public-private partnership, where " $[\mathrm{t}]$ he current [land] owners will finance the start of the mobility enterprise during the development phase. The parties concerned will secure the maintenance of the mobility enterprise during the utilization phase" [22]. As a first key role, a mobility director will be the head of the enterprise and be responsible for the day-to-day operations and continuous development of the mobility concept, as well as the safeguarding of public values. "The director has to be independent and will be monitored by a steering committee in the public-private partnership," said respondent S1. Two other foreseen key roles are an operator of (shared) mobility services, i.e. who provides a digital platform and "the wheels" (either directly or using a subcontract), and an operator of parking garages who is prepared to depart from traditional business models and talk about 'mobility space' rather than 'parking space'.

While the above observations indicate a shared sense of direction among the actors involved in the development of Merwede, a recent market study on the opportunities for tendering parts of the operation of the mobility concept [21] revealed that questions remain as to what entails the work of these prospective concessionaires. For instance, whereas some respondents addressed that many tasks could be fulfilled by the same actor, others preferred a strict separation of responsibilities between different concessionaires, and yet others addressed the opportunity to generate competition and avoid vendor lock-in by having multiple service providers offer similar services within the neighbourhood. Also, some market actors expected a public entity to become the mobility director (as a "market manager"), while others defined the director as a "commerciallydriven platform provider" ([21], p. 7).

\subsection{Decision-making processes}

The case of Merwede reveals at least two governance challenges regarding decision-making processes. First, the staging of public participation for developing and operating the mobility concept; second, the tensions that arise from dealing with different, sometimes competing planning and investment horizons.

\subsubsection{Public participation process}

Interview respondents admitted having doubts about involving other stakeholders than landowners and developers in the making of Merwede's mobility arrangement. The most peculiar questions here are how to define 'the 
public' and how to build a sense of ownership regarding the mobility concept among future users, including future residents of the neighbourhood. "The role and influence of residents are important to the aldermen who are involved in this project", said respondent S1. According to him, the aldermen are in favour of reaching out to potential residents of Merwede, approximately 75 people who have already shown interest in living in the new neighbourhood. However, respondent S1 also stressed how time and energy-consuming such an operation would be, and that success would not be guaranteed. Respondent S4 backed this statement and added that it would be difficult to arrange a highly inclusive process, also given the unwillingness of some landowners to open up the process to future residents.

Earlier accounts of public participation in the operation of the mobility concept emphasized that users will not have a direct vote in the proposed mobility enterprise; the shareholders of the public-private partnership will make decisions on behalf of residents and businesses in the area [6]. More recently, market actors confirmed the importance of user involvement, yet acknowledged the risk of qualifying users as shareholders of the mobility concept, its development, and its operations ([21], pp. 17-18). The shareholders of the Collective of Owners concur that the mobility platform is to anticipate and respond to changing user preferences and needs, and that therefore service operators must know and understand the user. However, direct participation of (potential) users has hitherto been out of the question. Instead, the Collective has been using assumptions for user behaviour. In a 2018 advisory report, Boshouwers et al. (pp. 14-15) made a segmentation of user groups: "young digitals", "child and career", "good city life", "elite top class", and "social tenants". Each group was assigned a set of propositions regarding mobility preferences and behaviour. Based on this segmentation, it has been proposed that market-rate apartments come with a higher proportion of rentable parking spots for private cars than social housing apartments. However, such a strategy would have significant implications for inclusivity (respondent S1). It has remained unclear how questions of user involvement will be resolved, especially when bearing in mind the diversity of the future community.

Unlike public participation in the making of Merwede's mobility concept, public participation for the bigger picture, i.e. the development of the neighbourhood as a whole, has taken off. This process has been characterized by a series of participation events, mainly at night and with an informative function-'public consultation evenings' [20]. Publicly available reports on these events indicate that participants, who often lived in neighbouring areas, were mainly concerned about the potential effects of Merwede on their communities. For instance, residents of Transwijk have been cautious about Merwede's low parking norm: they fear an influx of automobiles in their neighbourhood, which currently offers plenty of free parking space. Furthermore, residents of Rivierenwijk and houseboat owners (both located east of Merwede) have expressed concerns about plans to build bicycle bridges across the Merwedekanaal. As such the discussion in public has focused on negative externalities and the concerns of residents of adjacent neighbourhoods.

\subsubsection{Planning and investment horizons}

Internal discussions about Merwede's mobility concept unveiled tensions between landowners. The challenge becomes visible in discussions about the phasing of the project, which demonstrate different planning horizons of developers with different backgrounds and motivations. Early versions of the urban plan for Merwede were made with a differently constellated Collective of Owners than the most recent version. For instance, between the first and latest versions, an investment firm which owned a significant piece of land on the project site sold its lot - including the real estate - to an American real estate investor. The latter paid a rather high amount to achieve a position in the area, as land prices had gone up due to the imminent plans for Merwede. This American investor paid over 46 million euros in July 2018 where the previous owner had purchased the land and real estate for 31.75 million euro in September 2017 [29]. As a result, the late-coming investor had to develop a portfolio based on a different business case than the others: it has less time, yet needs to achieve a higher return on investment to turn its expensive land transaction into a profitable endeavour. The diversity of perspectives within the Collective of Owners has thus increased, and so has the complexity of the challenge of developing the mobility concept.

Many respondents admitted that the question of bringing together different planning horizons and business cases remains to be resolved. The key trick for the mobility concept to become successful is that all parties involved in the Collective of Owners financially contribute to its development and operation. However, as some developers have been applying longer time horizons than others, it has become difficult to make decisions about how, why, and when those who have skin in the game come in or leave the project site, and what they bring in and take out resource-wise. The financial viability of the mobility concept benefits from long-term financial commitments, yet here "there is bound to be adversity between the business cases of different developers," said respondent $\mathrm{S} 1$. 


\subsection{Instruments}

In terms of instruments to be used in the governance of Merwede's mobility concept, respondents mainly referred to the digital platform and how it will evolve. We observed ambiguity about what this platform should comprehend, and uncertainty about how the concept and the platform will unfold over time, which raises contractual challenges.

\subsection{1 "The platform" defined}

Where mobility arrangements for new neighbourhoods come with digital solutions, market logic is likely to become a key governance mechanism: public actors are required to contract private partners to deliver and operate a platform. It then becomes crucial to clearly define what a mobility platform should entail, what the scope of a platform is, what it should do, and when it is considered a success. Yet in many publicly available documents on the plans for Merwede, information about the platform has either been vague or absent. Respondent S5 confirmed this and commented that clarity will be given once the City of Utrecht and the Collective of Owners have defined a clear assignment to be published as a tender.

Our analysis indicated a variety of definitions of "the platform" for Merwede. On the one hand, through workshops and interviews, we came across notions that the mobility concept should be of use for commuting and any other daily urban activities and facilities (e.g. grocery shopping, day-care centres, distribution of goods, service transport) and that the platform could serve all these purposes and more. It could reach far beyond mobility by including questions of waste and energy (cf. [6], pp. 18-19). In other sessions and among other respondents we observed a preference for a less comprehensive platform, focusing solely on mobility. For instance, respondent S1 considered the platform a personal travel assistant that offers full-fledged mobility advice, with seamless integration of different transport modes; "No more messing around." All respondents agreed to incorporate shared mobility and public transportation in the platform; some preferred to also incorporate parking operations. In any case, it was to be avoided that users have to use different applications to use different transport modes.

As diverse as the perspectives on the scope of Merwede's platform were the viewpoints on its business model. Respondents addressed a series of outstanding questions. Examples include: how to set user tariffs and how to tweak these between different times of the day?; is the platform operator to be rewarded when shared cars are always available, or when people rent cars as little as possible-i.e. when travel behaviour has become more sustainable?; how to make money from mobility in a neighbourhood where active, free transport-cycling, walking-is prioritized? One of the original plans was to request owner-occupiers and tenants to pay an annual fee of 1 euro per square metre of floor space to fund the services offered by a mobility director, which would amount to 700.000 euro annually (respondent S1). However, landowners involved in the Collective of Owners have been worried about the complexity of this payment structure, and for housing associations it will legally be difficult to make such requests to tenants, especially in the case of low-income households.

\subsubsection{Concept and platform over time}

For Merwede's mobility concept to become a (financial) success and truly become a part of the communities and lives of residents, mobility providers and users have to be involved for the long haul. A profitable business case is not to be expected in the early years of operation, which will be signified by experimentation and learning regarding the workings of a mobility concept at this scale ([21], pp. 20-21). Furthermore, both in the short and long term, the concept has to be robust: if a crisis hits, market conditions change, travel patterns shift, or any other perturbation occurs, the mobility concept should be flexible enough to continue delivering mobility solutions to travellers. Alternatively, it should be resilient enough to find other ways of generating cash flow and remain in operation. Our document analysis indicated that the mobility concept will likely have a dynamic character. The proposed mobility enterprise and platform are expected to grow in size and evolve gradually, depending on the progress made with the development of the new neighbourhood. Also, ownership of the mobility enterprise will shift over time: once the neighbourhood is complete, it will no longer be the current landowners who are in charge of the enterprise, but real estate owners and the City of Utrecht in its public-law role [6].

Ironically, even though flexibility and resilience harness long-term operability, they do not naturally go hand in hand with the certainty and comfort that may be aspired by concessionaires for mobility services or other actors involved in Merwede. Regarding the institutional structure of the mobility enterprise, respondent S1 commented that it will change over time as developers will sell real estate to investors: "Then, the outstanding question is: how can we make arrangements now that can endure these institutional changes, and that can be changed if required?" Similar questions remain to be resolved regarding the service level offered by providers over time, as the neighbourhood becomes more complete. For instance, in an early development stage, several hundreds of people will be living in Merwede. At this stage, it would make sense to make available 
approximately 10 shared cars. However, as essential parts of the mobility concept, the mobility shop and the mobility platform will have to be fully operational from day one [6]. The City of Utrecht and the Collective of Owners have been negotiating about how to deal with these complex and continuously changing variables. Respondent S2 proposed to establish a dynamic set of requirements for the procurement of the mobility platform: to aim for flexible, open 'development contracts' rather than rigid 'performance contracts'.

Not only future contracts require significant changes over time; existing contracts are particularly prone to change, and not without consequences. Signed and operating concession agreements for regional public transit provide an example. While the government of the Province of Utrecht has tendered a concession to a transit operator for 10 years (2013-2023), the arrangements made are bound to be affected by Merwede's mobility concept: the City of Utrecht will seek to adjust bus routes and improve connections between transport modes. However, changing operating contracts will come at a cost: contractual variations trigger a loss of income for either the concessionaire or the public-sector client.

\section{Conclusion and discussion}

The Merwede project epitomizes a recent worldwide trend on the nexus of digital innovation, mobility, and city building, exhibiting a pioneering effort to integrate a mobility platform into the institutional and spatial context of a new neighbourhood. In this article we have studied governance challenges that arise in such a development. We came across several outstanding questions, and by discussing some of the most challenging ones we provided empirical insights that bear relevance to the practice of making and operating mobility platforms that are to be connected to new and existing neighbourhoods.

First, regarding organizational structures, we discussed the complex actor constellation and concomitant ownership and responsibility issues that we observed in the process. The analysis showed that the novelty of Merwede's mobility concept has come with questions about how to divide tasks during the development phase and which new roles and institutions to establish for the operating phase of the neighbourhood (cf. [50]). Also, our case shows how the interaction between developing MaaS and urban planning processes could play out. Merwede's mobility platform will be developed and operated in connection to its physical environment, as both the municipality and all other landowners in the area are involved in the making of that platform (cf. [39]). However, an important caveat is in place here: many of the actual decisions about the mobility platform still have to be made.

Second, the public participation process for Merwede as a whole proved conventional, focusing mainly on the concerns of citizens living in the adjacent neighbourhoods that will be directly affected. Public participation on the mobility concept has been non-existent. In that sense the case of Merwede has not (yet) addressed the issue raised by Frenken and Schor [33] that digital innovations are often implemented without deep debates upfront. Furthermore, internal discussions in the project have revolved around the different perspectives on the business case(s) of the development of the neighbourhood in combination with the viability of the mobility concept, and not so much about setting up and operating an elaborate public participation process with (future) residents. Without there being a deal between the landowners, a new mobility concept is likely to fail. Therefore, it has hitherto been a priority for the actors involved to focus on the viability and feasibility of the plans rather than on public participation.

Third, we addressed the key instrument of Merwede's mobility concept: the mobility platform. We presented various views on the definition, scope, and success factors of the platform to illustrate that there has not been an unambiguous understanding of what it should be and do. A public procurement procedure is necessary before a platform provider and operator can be contracted, yet what is to be included in the concomitant contract remains a topic of discussion among the landowners on the project site. Also, we discussed how a current lack of clarity about the platform increases uncertainty about its future and that of other, related instruments, including both existing and prospective contracts and concessions related to mobility. All in all, this empirical study of Merwede indicates the vast complexity of an endeavour this unconventional.

To conclude this article, it is worthwhile to observe that there is now a widespread academic consensus about the value of having new conversations on digital technologies and how they pervade the urban fabric (see for instance [48]). Yet, in our case of Merwede these conversations have hitherto been lacking. Other initiatives of platform urbanism and 'smart neighbourhoods' across the globe have met with stronger opposition-for instance the plans that Sidewalk Labs had for Quayside on the Toronto waterfront $[43,47]$. Such different experiences points to the need for future scholarship to systematically compare the different ways of staging debates about the conjunction between sustainable urban planning and the platformization of mobility services. We hope that with this in-depth elaboration of the case of Merwede we have contributed to this critical agenda for policy and research.

\section{Acknowledgements \\ Not applicable.}

Authors' contributions

PP developed the original idea for this research project and was the leading author of the research proposal for Het Algoritmisch Atelier. All authors were involved in collecting the data (documents, interviews, workshops) regarding 
Merwede's mobility concept. MH analyzed and interpreted the data for this manuscript and was a major contributor in writing the manuscript. PP, and $\mathrm{RR}$ revised parts of the manuscript and delivered substantial amounts of feedback. All authors read and approved the final manuscript.

\section{Funding}

This work is part of the research program Smart Urban Regions of the Future (VerDuS SURF). The research project is titled Het Algoritmisch Atelier (The Algorithmic Studio) and is (partly) financed by the Dutch Research Council (NWO).

\section{Availability of data and materials}

The datasets generated and/or analyzed during the current study are not publicly available due to political and commercial confidentiality and sensitivity, but are available from the corresponding author on reasonable request and with permission of the City of Utrecht.

\section{Declarations}

\section{Competing interests}

The authors declare that they have no competing interests.

\section{Author details}

${ }^{1}$ Department of Human Geography and Spatial Planning, Utrecht University, Princetonlaan 8a, 3584, CB, Utrecht, The Netherlands. ${ }^{2}$ Radboud Institute for Culture and History, Radboud University Nijmegen, Erasmusplein 1, 6525 HT Nijmegen, The Netherlands.

\section{Received: 13 July 2020 Accepted: 12 March 2021}

Published online: 23 March 2021

\section{References}

1. Arcadis (2017). PlanMER omgevingsvisie Merwedekanaalzone: deel A. Arcadis.

2. Barns, S. (2020). Platform Urbanism: Negotiating Platform Ecosystems in Connected Cities. Palgrave MacMillan.

3. Berghauser Pont, M., \& Haupt, P. (2010). SPACEMATRIX: Space, Density and Urban Form. NAi.

4. Boarnet, M. G., \& Crane, R. (2001). Travel by Design: The Influence of Urban Form on Travel. Oxford University Press.

5. Boffey, D. (2020). Forward-thinking Utrecht builds car-free district for 12,000 people. The Guardian, 15 March. Available at: https://www.theguardian. com/world/2020/mar/15/forward-thinking-utrecht-builds-car-free-districtfor-12000-people (Accessed 11 June 2020).

6. Boshouwers, R., Kandel, H., Govers, B., \& Van der Linde, L. (2018). Mobiliteitsconcept voor Merwede. Eindrapport. Goudappel Coffeng and Rebel.

7. Bouckaert, G., Peters, G., \& Verhoest, K. (2010). The Coordination of Public Sector Organizations: Shifting Patterns of Public Management. Palgrave Macmillan.

8. Buitelaar, E. (2010). Window on the Netherlands. Cracks in the myth: challenges to land development policy in the Netherlands. Tijdschrift voor Economische en Sociale Geografie, 101(3), 349-356.

9. Churchman, A. (1999). Disentangling the concept of density. Journal of Planning Literature, 13(4), 389-411.

10. City of Utrecht (2004). Visie Merwedekanaalzone. City of Utrecht.

11. City of Utrecht (2013). Nota parkeernormen fiets en auto. City of Utrecht Available at: https://www.utrecht.nl/fileadmin/uploads/documenten/wonenen-leven/parkeren/NSP2013_Nota-Parkeernormen-Fietsen-Auto.pdf (Accessed 11 June 2020).

12. City of Utrecht (2015a). Bouwen aan een gezonde toekomst: een uitnodiging aan de stad. Volksgezondheidsbeleid 2015-2018. City of Utrecht.

13. City of Utrecht (2015b). Utrecht aantrekkelijk en bereikbaar: Actieplan Utrecht Fietst! 2015-2020. City of Utrecht.

14. City of Utrecht (2015c). Utrecht aantrekkelijk en bereikbaar: Zuid Zuidwest. Gebiedsagenda. City of Utrecht.

15. City of Utrecht (2016a). Gemeentelijk verkeers- en vervoerplan. City of Utrecht.

16. City of Utrecht (2016b). Slimme routes, slim regelen, slim bestemmen. Mobiliteitsplan Utrecht 2025. City of Utrecht.

17. City of Utrecht (2016c). Utrecht kiest voor gezonde groei. Ruimtelijke strategie Utrecht 2016. City of Utrecht.

18. City of Utrecht (2018a). Merwede, deelgebied 5: overzicht grondeigenaren Available at: https://www.utrecht.nl/fileadmin/uploads/documenten/wonen-
en-leven/bouwen/bouwprojecten/merwedekanaalzone/2018-03-Merwededeelgebied-5-overzicht-grondeigenaren.pdf (Accessed 11 June 2020).

19. City of Utrecht (2018b). Omgevingsvisie Merwedekanaalzone. Deel 1: ruimtelijke agenda voor de toekomst van de Merwedekanaalzone. City of Utrecht.

20. City of Utrecht (2019). Omgevingsvisie Merwedekanaalzone. Deel 2: uitwerking van de ruimtelijke agenda. City of Utrecht.

21. City of Utrecht (2020a). Marktverkenning: mobiliteitsdiensten en parkeren Merwede. Verslag. City of Utrecht.

22. City of Utrecht (2020b). Marktverkenning: mobiliteitsdiensten en parkeren in gebiedsontwikkeling Merwede. Vooraankondiging. Available at: https:// www.tenderned.nl/tenderned-tap/aankondigingen/186561;section=3 (Accessed 12 June 2020).

23. Davis, D. E. (2018). Governmental capacity and the smart mobility transition. In G. Marsden, \& L. Reardon (Eds.), Governance of the Smart Mobility Transition, (pp. 105-122). Emerald Publishing.

24. Docherty, I. (2018). New governance challenges in the era of 'smart' mobility. In G. Marsden, \& L. Reardon (Eds.), Governance of the Smart Mobility Transition, (pp. 19-32). Emerald Publishing.

25. Docherty, I., Marsden, G., \& Anable, J. (2018). The governance of smart mobility. Transportation Research Part A: Policy and Practice, 115, 114-125.

26. Eigenarencollectief Merwede (2017). Schetsontwerp stedenbouwkundig plan Merwede. Eigenarencollectief Merwede.

27. Eigenarencollectief Merwede (2019). Beeldkwaliteitsplan Merwede. Eigenarencollectief Merwede.

28. Eigenarencollectief Merwede (2020). Voorlopig ontwerp stedenbouwkundig plan Merwede. Eigenarencollectief Merwede.

29. Engelman, L. (2019). Merwedekanaalzone (2) - Op het verkeerde been. Nieuws030, 22 January. Available at: https://www.nieuws030.nl/achtergrond/ merwedekanaalzone-2-op-het-verkeerde-been/ (Accessed 10 Dec 2020).

30. Ewing, R., \& Cervero, R. (2001). Travel and the built environment: a synthesis. Transportation Research Record, 1780(1), 87-114.

31. Flyvbjerg, B. (2006). Five misunderstandings about case-study research. Political Inquiry, 12(2), 219-245.

32. Frenken, K., \& Pelzer, P. (2019). Reverse technology assessment in the age of the platform economy. Built Environment, 46(1), 22-27.

33. Frenken, K., \& Schor, J. (2017). Putting the sharing economy into perspective. Environmental Innovation and Societal Transitions, 23, 3-10.

34. Hajer, M., Pelzer, P., Van den Hurk, M., Ten Dam, C., \& Buitelaar, E. (2020). Neighbourhoods for the Future: A Plea for a Social and Ecological Urbanism. Trancity $\times$ Valiz.

35. IRP (2018). The Weight of Cities: Resource Requirements of Future Urbanization. International Resource Panel, United Nations Environment Programme.

36. Kwantes, C., Van der Linde, L., Brands, T., \& Terlouw, D. (2019). Mobiliteit Merwedekanaalzone. Goudappel Coffeng.

37. Lehmann, S. (2019). Urban Regeneration: A Manifesto for Transforming UK Cities in the Age of Climate Change. Palgrave Macmillan.

38. Meijer, A. (2018). Datapolis: a public governance perspective on "smart cities". Perspectives on Public Management and Governance, 1(3), 195-206.

39. Pangbourne, K., Mladenović, M. N., Stead, D., \& Milakis, D. (2020). Questioning Mobility as a Service: Unanticipated societal and governance implications. Transportation Research Part A: Policy and Practice, 131, 35-49.

40. Pelzer, P., Frenken, K., \& Boon, W. (2019). Institutional entrepreneurship in the platform economy: How Uber tried (and failed) to change the Dutch taxi law. Environmental Innovation and Societal Transitions, 33, 1-12.

41. Poell, T., Nieborg, D., \& van Dijck, J. (2019). Platformisation. Internet Policy Review, 8(4), 1-13.

42. Reid, C. (2020). 12,000 residents, zero cars: Utrecht's new city district to prioritize pedestrians and cyclists. Forbes 6 February. Available at: https:// www.forbes.com/sites/carltonreid/2020/02/06/12000-residents-zero-carsutrechts-new-city-district-to-prioritize-pedestrians-and-cyclists/\#3c58ff734334 (Accessed 25 June 2020).

43. Saxe, S., \& Siemiatycki, M. (2019). How Toronto reined in big tech. The New York Times 1 November. Available at: https://www.nytimes.com/2019/11/01/ opinion/how-toronto-reined-in-big-tech.html (Accessed 10 Dec 2020).

44. Scharpf, F. W. (1997). Games Real Actors Play: Actor-centered Institutionalism in Policy Research. Westview Press.

45. Stehlin, J., Hodson, M., \& McMeekin, A. (2020). Platform mobilities and the production of urban space: Toward a typology of platformization trajectories. Environment and Planning A: Economy and Space, 52(7), 1250 1268. 
46. Thompson, G., Frances, J., Levačić, R., \& Mitchell, J. (Eds.) (1991). Markets, Hierarchies, and Networks: The Coordination of Social Life. Sage.

47. Valverde, M., \& Flynn, A. (2018). Mystery on the Waterfront: How the "smart city" allure led a major public agency in Toronto into a reckless deal with big tech. Centre for Free Expression, Ryerson University Available at: https://cfe. ryerson.ca/blog/2018/12/mystery-waterfront-how-smart-city-allure-led-majorpublic-agency-toronto-reckless-deal (Accessed 10 Dec 2020).

48. Valverde, M., \& Flynn, A. (2020). Smart Cities in Canada: Digital Dreams, Corporate Designs. Lorimer.

49. Van den Hurk, M. (2015). What's the Deal? Standardizing Contracts for PublicPrivate Partnerships. PhD dissertation. University of Antwerp.

50. Van der Graaf, S., \& Ballon, P. (2019). Navigating platform urbanism. Technological Forecasting and Social Change, 142, 364-372.

51. Van der Linde, L., Oldenburger, A., Kwantes, C., Govers, B., \& Boshouwers, R. (2018). Conceptontwikkeling mobiliteitsconcept Merwede. Onderliggende notitie 1, behorend bij het eindrapport 'Mobiliteitsconcept voor Merwede'. Goudappel Coffeng and Rebel.

52. Van Dijck, J., Poell, T., \& De Waal, M. (2018). The Platform Society: Public Values in a Connective World. Oxford University Press.

53. Van Doorn, N. (2019). A new institution on the block: on platform urbanism and Airbnb citizenship. New Media \& Society, 22(10), 1808-1826.

54. Van Kerkhoff, R., \& Rothengatter, R. (2019). Aanvulling PlanMER Merwedekanaalzone Utrecht. City of Utrecht.

55. Van Kooten Niekerk, M. E., Van den Akker, J. M., \& Hoogeveen, J. A. (2017). Scheduling electric vehicles. Public Transport, 9, 155-176.

\section{Publisher's Note}

Springer Nature remains neutral with regard to jurisdictional claims in published maps and institutional affiliations.

\section{Submit your manuscript to a SpringerOpen ${ }^{\circ}$ journal and benefit from:}

- Convenient online submission

- Rigorous peer review

- Open access: articles freely available online

- High visibility within the field

- Retaining the copyright to your article

Submit your next manuscript at $\boldsymbol{\nabla}$ springeropen.com 